\section{Directives and requirements for genetically modified (GM) crop regulation in Argentina}

\section{Daniela Inés Orroño ${ }^{1^{*}}$ and Facundo Vesprini ${ }^{2}$}

\begin{abstract}
Regulation of GM crops prior to their commercial release requires research under controlled conditions, either in confined field trials, in greenhouses, and/or in the laboratory. Authorizations in Argentina can be obtained for experimental or confined field trials and "counter-season" production of regulated seed. These trials represent the first controlled introduction of GM crops in the environment. The goal is to prevent dissemination of GM pollen, seed, or plant parts outside the growing area and avoid consumption by humans and animals. During the trials, data is also collected on agronomic performance and potential environmental impacts. The purpose of this document is to provide a summary of the regulatory requirements governing contained and confined field trials of GM crops in Argentina.
\end{abstract}

Key words: Regulatory framework, biosafety, confined field trials, contained activities, isolation distances.

\section{INTRODUCTION}

Worldwide, applications for commercial release of genetically modified (GM) crops began in the mid-1990s. Global biotech crop area has increased more than 100-fold from 1.7 million hectares in 1996 to 179.7 million hectares in 2015 (James 2015). Commercial release and adoption of these crops has contributed to reduce the risk of crop losses from insects and weeds, has reduced pesticide and fuel use, and has increased yields (Carpenter 2010, Edgerton et al. 2012, Brookes and Barfoot 2015). However, commercial releases of GM crops have aroused biosafety concerns and controversy worldwide. Therefore, their regulation is essential to address the biosafety concerns associated with $\mathrm{GM}$ crops and their products.

Argentina has a long history of GM crop cultivation. The first confined field releases were authorized for experimental purposes in 1991. In 1992, GM crops were also authorized exclusively for seed multiplication and export purposes (Burachik 2012). These exports included "counter-season" production of GM maize and soybean seed not yet approved for commercial release in Argentina.

The Argentine regulatory system for biotechnology encompasses release for confined trials in the field or greenhouses, off-season production of regulated seed for export to countries where the GM crop is deregulated, and assessment for commercial release. These activities are carried out by the Nacional Advisory Commission for Agricultural Biotechnology (Comisión Nacional Asesora de Biotecnología Agropecuaria - CONABIA), through the Biotechnology Directorate of the Ministry of Agroindustry. This government agency basically works in two
Crop Breeding and Applied Biotechnology 18: 301-308, 2018 Brazilian Society of Plant Breeding. Printed in Brazil http://dx.doi.org/10.1590/1984$70332018 v 18 n 3 r 44$
*Corresponding author: E-mail: dorrono@magyp.gob.ar

Received: 28 July 2017 Accepted: 08 September 2017

${ }^{1,2}$ Biotechnology Directorate of Agroindustry Ministry, 922 Paseo Colon Avenue, Autonomous City of Buenos Aires, Argentina 


\section{Orroño and F Vesprini}

areas of assessment: the first and second stage of evaluation. The main goals of the first stage are to prevent escape of the transgenes in pollen, seed, or other plant parts from confinement and their persistance in the environment and to prevent consumption of plant material by humans and animals. The main goal of the second stage of evaluation is assessment of environmental risk in commercial release of the GM crop.

Commercial release involves three evaluations. They are the food and feed evaluation, environmental risk assessment, and assessment of economic impact on Argentine agricultural production and in commerce. These assessments are made by the National Service of Agricultural Food Health and Quality (Servicio Nacional de Sanidad y Calidad Agroalimentaría - SENASA), CONABIA, and the Undersecretariat of Agricultural Markets (Subsecretaria de Mercados Agropecuarios), respectively. Each evaluation is independent of the others and the findings of each are non-binding on the agency decision for commercial release of the GM crop.

Argentina is the third largest grower of biotech crops in the world, after the United States and Brazil (James 2015). The first GM crop approved for commercial release in the country was the glyphosate-tolerant soybean in 1996 . Since then, Argentina has approved $40 \mathrm{GM}$ crops for commercial release (for more information see: http://www.agroindustria.gob. $\mathrm{ar} / \mathrm{sitio} /$ areas/biotecnologia/ogm/). Most GM crop approvals have involved traits that provide herbicide tolerance (HT) and/or insect resistance (IR), followed by stacked (pyramided) traits. However, cultivars with other traits have recently been assessed and approved; these include traits that provide better agronomic performance (drought tolerance), enhanced product quality (high oleic acid), or resistance to pathogens (virus resistance).

Argentine national government has chosen biotechnology as one of the strategic areas for national development. In recent years, there has been increased interest in developing traits that increase the performance of local crop varieties. Much of the research and development (R\&D) in Argentina is being conducted in national research institutes and universities. In October 2015, the Argentine government approved commercial release of a drought-tolerant soybean that contains a sunflower gene $(\mathrm{Hb} 4)$ related to the natural response to abiotic stress. This was the first droughtresistant soybean approved in the world. On the same date, the government also approved commercial release of the genetically-engineered potato resistant to Potato Virus Y (PVY). These two crops were the first local varieties developed in the country, and R\&D was based on public-private partnerships.

Argentina has been one of the pioneers among Latin American countries in regulation and approval of biotechnology products. In October 2014, CONABIA was recognized by the FAO as a "Reference Center in Biotechnology". Argentine knowledge, experience, and expertise in regulatory issues and FAO recognition establish Argentina as one of the worldwide leaders in GM crop regulation.

This review presents some relevant regulatory issues that should be considered during confined field trials of GM crops in order to prevent their escape, spread, and persistence in the environment and their consumption by humans or animals.

\section{OVERVIEW OF THE REGULATORY FRAMEWORK FOR CONFINED EXPERIMENTS}

Before deregulation or commercial release, GM plants are usually tested in "contained" greenhouses (greenhouses with containment procedures) or confined field trials in order to provide risk assessment data. These trials are conducted under strict management practices in order to prevent dissemination of the modified species outside the growing area (Garcia-Alonso et al. 2014).

Argentina considers a "regulated" GM crop as non-commercial; therefore, the use of such plants outside the constraints of physical containment (e.g., in a field) is forbidden. These biotech-derived plants are regulated under the Law on Seeds and Phytogenetic Creations and the Law on the Promotion of the Development and Production of Modern Biotechnology. Regulatory responsibility depends on the Secretariat of Food and Bioeconomy (formerly, the Office of Agriculture, Livestock, Fisheries and Food). Additionally, registration in The National Registry for Operators with Genetically Modified Plants Organisms is a prerequisite to request authorization for confined trials of GM plants, as well as for import or export of GM seed (Resolution 17/2013). Argentina carries out risk assessment on a case-by-case basis (each GM crop must have a separate evaluation and particular considerations) and regulates the final products, not the process applied in obtaining the GM crop. 
Applications for confined trials are submitted to the National Institute of Seeds - Special Biotechnology Projects (INASE-PEB), the government agency in charge of registering and controlling the seed market and monitoring field trials. Applications are then forwarded to the Biotechnology Directorate (BD), where a group of technical evaluators analyzes the full proposals and provides support on supervision of the confined activities. After that, the conclusion is forwarded to CONABIA. This is a multidisciplinary and inter-institutional advisory group composed of representatives from public and private institutions with a wide range of expertise in agricultural biotechnology. This commission evaluates the scientific and technical issues associated with the confined trials and the environmental risk in commercial release of biotech products, and it makes recommendations to the Secretariat of Food and Bioeconomy, which makes the final decisions and official resolutions. Following the complete review process, authorization may be granted or will be denied.

\section{ENVIRONMENTAL RELEASE OF REGULATED GM CROPS IN ARGENTINA: NATIONAL LEGISLATION}

Regulatory requirements for GM crops vary among different countries. In Argentina, any release of a regulated GM plant into the environment requires authorization. Applications must be submitted for each modified plant species. Each application can include many release sites and authorize many different gene constructs to be tested at each site.

Releases into the environment are governed by three guidelines (http://www.agroindustria.gob.ar/sitio/areas/ biotecnologia/solicitudes/) under specified terms and conditions. Authorizations can be obtained for confined releases in three situations: confined field trials (S.A.G.y P. № 701/2011), production of regulated seed (S.A.G.y P. № 17/2013), and cultivation in biosafety greenhouses (S.A.G.y P. № 241/2012.).

\section{RESOLUTION S.A.G.Y P. № 701/2011 REGULATES ENVIRONMENTAL RELEASES OF REGULATED GM PLANTS IN ARGENTINA, EITHER IN FIELD TRIALS OR GREENHOUSES}

This resolution is applicable to small-scale field trials carried out in multiple sites, confined to a limited area, and performed under stringent terms and conditions. The directives are divided into four modules: Module A "General Information", Module B "Information on the event or construct", Module C "Agronomic and Biosafety Information", and Module D "Information about the release sites". Applicants must provide detail on ensuring biosafety conditions, particularly isolation distances, measures to prevent entrance of animals, the obligation to facilitate access to inspectors, methods of machinery cleaning (hand-cleaning, compressed air, and vacuuming), period during which restrictions on planting the same crop apply, post-harvest monitoring of volunteer plants, and any other necessary biosafety conditions.

Regulatory authorities may require periodic inspections or reports on the progress and compliance of the trial. Inspectors from INASE or SENASA are responsible for the inspections. SENASA regulates the import/export of the seed and interstate movement, while INASE monitors production. Every trial is subject to inspections: during the growing season, before planting, at planting, and at harvest (Isolation and Trial Progress Reports); after harvest (Harvest Report); and after trial termination (Closure Report and Post-trial Monitoring Report). The Post-trial Monitoring Report is an essential step in monitoring volunteers. The Closing Report is mandatory for future regulated releases and must include date and method of harvest, final disposal or storage site of harvested materials, and the method of destruction of any residual plant material. It must also include behavioral observations on GM crop agronomic attributes concerning germination, vegetative growth, flowering, susceptibility to diseases and pests, and effects on non-target organisms. This last item of information is used to address possible unintended effects that will be assessed in the future presentation of environmental risk assessment for commercial release of the GM crop.

\section{RESOLUTION S.A.G.Y P. № 17/2013 REGULATES PRODUCTION OF REGULATED GM SEED OR BIOMASS}

This resolution deals with seed production of GM maize or soybean and biomass production of regulated materials for industrial use (production of biofuels, recombinant proteins, and enzymes). Seed production is restricted to multiplication of seed and re-exports to countries where the GM crop is deregulated (especially counter-season production). This allows transnational seed companies to grow seed in the southern hemisphere in order to have two rounds of breeding trials per year. Production of regulated seed is permitted only under strict isolation and seed processing conditions to ensure that regulated material does not enter the food/feed chain or spread in the environment. The seed producer is legally 
obliged to notify INASE of every movement of the regulated seed from arrival of the seed in Argentina to final export of the multiplied seed. The volumes of seed imported are controlled by SENASA, and the volumes of seed produced by the multiplication procedure are monitored by INASE. Regulated bags of GM seed are identified by orange-colored labels to ensure seed traceability.

Immediately after production of regulated seed, the equipment is purged to remove residual regulated seeds. Machinery must be cleaned after the harvest of a GM crop by harvesting a specified area of a non-GM cultivar. The seed lot used to purge the machinery should ensure unequivocal detection of GM seeds and must be tested for the adventitious presence of GM seeds using the International Seed Testing Rules. Recommended legal thresholds for maximum adventitious presence of GM seeds in non-GM seed lots are $0.01 \%$ for maize and $0.07 \%$ for soybean. When the relevant threshold is exceeded, the purge procedure must be repeated until the presence of unauthorized GM seeds is under the limits mentioned. Any material collected during cleaning that exceeds the legal threshold must be destroyed according to the terms and conditions proposed and evaluated in the authorization.

\section{RESOLUTION S.A.G.Y P. № 241/2012 REGULATES BIOSAFETY GREENHOUSE ACTIVITIES OF GM PLANTS}

This resolution regulates "contained activities" (activities with containment procedures) carried out within greenhouses in Argentina. It involves activities conducted at the earliest stages of GM plant development. Greenhouses are a wellaccepted containment strategy for growing GM plants. The purpose of containment is to prevent and minimize the spread of transgenic pollen, seed, or other propagative material from GM plants to outside the greenhouse.

There are two greenhouse biosafety (BS) levels: BS1 and BS2. To determine the appropriate biosafety level, the presence of sexually compatible wild or weed species and the potential for outcrossing between recipient organisms and nearby related species must be considered (Table 1). Level BS1 specifies the physical and biological containment conditions required for non-weed species with no possibility of outcrossing with local weed species. Level BS2 specifies the physical and biological containment conditions required for species with possibility of outcrossing with local weed species. The applicants must provide detailed information related to the research activities performed in the facility. A book of activities (with record kept of experiments) and inventory book (movement in/out of greenhouse) is mandatory to keep records of all activities within the greenhouse. Two reports must be submitted to INASE for analysis by the BD and CONABIA: every six months, the applicant must submit a copy of the inventory book; and annually a copy of the book of activities. In addition, greenhouse facilities must be inspected by INASE for compliance with established biosafety standards.

Several New Breeding Techniques (NBT) are currently being implemented and represent a significant step forward for crop improvement compared with traditional breeding. Some NBT products are genetically similar to, or may be even

Table 1. Structural characteristics of greenhouses and Biosafety (BS) levels

\begin{tabular}{|c|c|c|}
\hline & BS1 & BS2 \\
\hline Physical structure & \multirow{2}{*}{$\begin{array}{l}\text { Aluminum, galvanized steel, wood, pipe } \\
\text { Perimeter fence of the facility, or main entrance with access } \\
\text { restricted to authorized personnel }\end{array}$} & IDEM BS1 \\
\hline Access & & IDEM BS1+ Double gateway \\
\hline $\begin{array}{l}\text { Walls } \\
\text { Insect screens in } \\
\text { openings }\end{array}$ & 640 micron pore maximum (minimum 40 mesh) & IDEM BS1 \\
\hline Ventilation & $\begin{array}{l}\text { Side and/or uppermost openings covered with screens, fans, } \\
\text { exhaust fans, and evaporation screens }\end{array}$ & IDEM BS1 \\
\hline Gutters & Of waterproof material & IDEM BS1 \\
\hline Drains & Shall drain into sanitary drainage systems or water systems & IDEM BS1 \\
\hline Grids & With mesh to prevent entry of animals and escape of seed & IDEM BS1 \\
\hline Others & $\begin{array}{l}\text { Preferably with automatic temperature control. Availability of } \\
\text { autoclave in adjacent or nearby facilities. Entry of any animal } \\
\text { should be prevented. }\end{array}$ & $\begin{array}{l}\text { Necessarily with automatic temperature control. Avail- } \\
\text { ability of autoclave in adjacent or nearby facilities. Entry } \\
\text { of any animal should be prevented. }\end{array}$ \\
\hline
\end{tabular}

Source: SAGyPA Resolution 241/2012 
indistinguishable from, traditionally bred plants (Schaart et al. 2016). In 2015, a new resolution (Resolution S.A.G.y P. № $173 / 2015$ ) included the regulation of NBT in plants. The purpose is to determine the cases in which a crop obtained by NBT is considered a GM plant or not. If the crop is considered GM, it will fall under the regulations applicable to GM plants.

\section{ISOLATION DISTANCES AND POST-HARVEST LAND USE RESTRICTION}

The "escape" of GM material is considered to be a potential problem associated with initial field testing and confined release of transgenic plants. In most crops, the two main sources of transgene escape are pollen (Dong et al. 2016) and seed (Ryffel 2014, Mallory-Smith et al. 2015). In general, pollen-mediated gene flow decreases exponentially with distance from the pollen source (i.e., it is inversely proportional to the distance) and is also affected by the type of pollinator and pollinator activity (Kavanagh et al. 2012, Hoffman et al. 2014, Yan et al. 2015, Dong et al. 2016). In contrast, seedmediated transgene flow results from volunteer transgenic plants emerging in fields, adventitious presence in seed, or human error during planting, harvesting, or seed processing (Ryffel 2014).

Minimum isolation distances required to avoid outcrossing have been established, as well as post-harvest land use restrictions, through consultation with academics, scientists, and stakeholders. There are internationally-recognized isolation distances that vary depending on the crop in question and its reproductive characteristics (Stachow et al. 2013, Devos et al. 2014). Seed certification standards (for basic and certified seed production) serve as a guide to establish minimum isolation distances for field trials of GM crops. The minimum isolation distances and periods of post-harvest land use restriction are given in Table 2.

Isolation and post-harvest land use restrictions will vary depending on the biology of the plant. The degree of isolation depends on pollen quantity and viability, type of pollen dispersal (wind and/or insects), synchrony of flowering, compatibility between pollen donor and receptor, and flower morphology (Baltazar et al. 2015). Self-pollinating crops such as soybean, tomato (Lycopersicon esculentum), potato, or wheat (Triticum aestivum) require relatively small isolation distances, primarily to prevent mechanical mixtures during harvesting. In contrast, cross-pollinating crops (maize and sunflower) or crops with a certain percentage of outcrossing rate, like cotton and rape (Brassica napus), may require more extensive isolation from plants of the same species to prevent outcrossing. Soybean has no sexually-compatible relative plants in Argentina, and the flower structure results in low levels of cross-pollination. Therefore, isolation distance for production of soybean seed is only the distance required to prevent mechanical mixing. Wheat is predominantly a self-pollinating species; fertilization usually occurs before the flowers open, although it is also a low wind-pollinated species. Its pollen is relatively heavy and settles quickly, making pollination from nearby fields unlikely (Rieben et al. 2011). Potato and tomato are predominantly self-pollinated crops, although bumblebees often perform some crosspollination. This situation may contribute to natural cross-pollination. Bravo-Almonacid et al. (2012) assessed gene flow between a transgenic cultivated genotype (4x) and a diploid wild potato in one season of a field experiment. The authors concluded that the probability of hybridization in the field is extremely low. According to Scaramussa Deprá et al. (2014), a small percentage of cross-pollination occurs in tomato, incrementing crop yield. Minimum isolation distances for potatoes and tomatoes are those required to prevent outcrossing under open-field conditions. In contrast, maize is

Table 2. Minimum isolation distances and periods of post-harvest land use restriction for environmental releases of experimental trials in Argentina

\begin{tabular}{|c|c|c|}
\hline Crop & Minimum isolation distance $(\mathrm{m})$ & Post-harvest land use restriction (years) \\
\hline Maize & $250 *$ & 1 \\
\hline Soybean & $3^{*}$ & 1 \\
\hline Cotton & $500-800$ & 3 \\
\hline Wheat & 3 & 2 \\
\hline Sunflower & 3000 & 2 \\
\hline Rape & 3000 & 5 \\
\hline
\end{tabular}

Source: SAGyPA Resolution 226/97

*Isolation distances for "counter-season" production of regulated maize seed are $250 \mathrm{~m}$ if the event is in the female parent line and $600 \mathrm{~m}$ if the event is in the male parent line. For "counter-season" production of regulated soybean seed, isolation distance is $30 \mathrm{~m}$. 


\section{Orroño and F Vesprini}

a cross-pollinated crop, relying on wind for pollen dispersal. Furthermore, it is not able to survive as a weed population outside cropped areas, due to its high degree of domestication (Sanchez et al. 2016). In the case of cotton, outcrossing is mediated by bees; therefore, outcrossing rates vary widely and depend on the number of pollinators present in a field (Yan et al. 2015). Thus, for maize and cotton, larger isolation distances may be applied. In contrast, sunflower (Helianthus annuus) and rape, which have many sexually-compatible relatives in Argentina (Gutiérrez et al. 2012, Tsuda et al. 2012), required greater isolation distances in order to minimize the possibility of transgene movement into weed relatives.

Regulated trials are usually not planted on land where the same species was grown the previous year, particularly for control of volunteer plants. The post-harvest restriction period depends on the plant species and especially on its seed dormancy characteristics. It is important to consider whether the genetic improvement is likely to have altered any properties of seed dormancy. Lack of germination is an indication of dormancy when seed health is confirmed by a viability test (Graeber et al. 2012). Knowledge of the persistence of viable conventional seed in the soil can be used to determine the appropriate period of post-harvest restriction and monitoring (CropLife International 2010). Crops that have little or no seed dormancy represent a lower risk since they germinate during normal periods and can be eliminated between crop intervals. Some crops, such as maize and soybean, do not exhibit seed dormancy, and their seeds will germinate quickly when exposed to adequate moisture and heat (Nakai et al. 2015). Therefore, monitoring for 1 year should be sufficient since it is unlikely that their seeds will remain viable in the soil for a longer period. In contrast, other crops (potato, rape, cotton, wheat, tomato, and sunflower) have seeds that delay germination for many months or years. Consequently, they require longer post-harvest land use restriction. Potato produces reproductive offspring, often in large numbers, and tuber dormancy reduces chances of the species being eliminated by unfavorable winter conditions (Rentzsch et al. 2012, Tavakoli et al. 2014). Likewise, the potential of rape seeds to persist in the soil and to emerge later as volunteers in following crops is mainly driven by the ability of the seeds to go into dormancy under certain soil conditions (Weber et al. 2013). Similarly, in cotton seeds, dormancy can be induced by low soil temperature and/or soil moisture. However, some forms of cotton may produce "hard seeds" that, upon drying, become impermeable to water and exhibit delayed germination (Baskin and Baskin 2014). In wheat, dormancy avoids seed germination during the preharvest stage (Carvalho et al. 2013). Sunflower and tomato seeds have physiological dormancy, and internal changes in hormone levels are needed for seed germination (Graeber et al. 2012, Gavassi et al. 2014, Dominguez et al. 2016).

Minimum isolation distance recommendations are dependent on the environment in which the crops are grown. Therefore, in special cases, applicants can choose alternative methods for reproductive isolation, such as harvest of plants before flowering; bags, nets, or cages placed over flowering plants to prevent pollen exchange; temporal isolation; removal of floral parts before pollen maturity; etc. The first stage of the Biotechnology Directorate and CONABIA will assess these proposals. If a trial is destroyed prior to harvest, applicants must provide information on the growth stage of the trial at the time of destruction, as well as the date and method of destruction, in order to establish a proper post-harvest period. It is the responsibility of the applicant to ensure that the conditions for the reproductive isolation and post-harvest land use restrictions of all trials are met.

\section{CONCLUSIONS}

Argentina was one of the first countries to adopt GM crops in Latin America and is currently the third largest grower of biotech crops in the world. As a commodity exporting country, Argentina's economy depends largely on agricultural production; therefore, biotechnology is an important item in the political agenda and plays a key role in the competitiveness of the country. The country has a well-defined, science-based risk assessment system that is productoriented, conducted on a case-by-case basis, and undertaken in a timely and efficient manner. For this reason, other countries follow Argentina as a reference in biotechnological regulatory affairs. Future challenges the regulatory system will face are harmonizing evaluation criteria between Argentina and importer countries in order to speed approvals to avoid transitory or permanent international trade disruptions.

\section{REFERENCES}

Baltazar BM, Castro Espinoza L, Espinoza Banda A, de la Fuente Martínez

JM, Garzón Tiznado JA, González García J, Gutierrez MA, Guzmán
Rodríguez JM, Heredia Díaz O, Horak MJ, Madueño Martínez JI, Schapaugh AW, Stojšin D, Uribe Montes HR and Zavala García F (2015) Pollen-mediated gene flow in maize: implications for isolation requirements and coexistence in Mexico, the center of origin of 
maize. PLoS ONE 10: 1-15

Baskin CC and Baskin JM (2014) Types of seed dormancy. In Baskin CC and Baskin JM (eds) Seeds, ecology, biogeography, and evolution of dormancy and germination. $2^{\text {nd }}$ edn, Academic Press, San Diego, p. 27-48.

Bravo-Almonacid F, Rudoy V, Welin B, Segretin ME, Bedogni MC, Stolowicz F, Criscuolo M, Foti M, Gomez M, López M, Serino G, Cabral S, Dos Santos C, Huarte M and Mentaberry A (2012) Field testing, gene flow assessment and pre-commercial studies on transgenic Solanum tuberosum spp. tuberosum (cv. Spunta) selected for PVY resistance in Argentina. Transgenic Research 21: 967-982.

Brookes G and Barfoot P (2015) Environmental impacts of genetically modified (GM) crop use 1996-2013: Impacts on pesticide use and carbon emissions. GM Crops \& Foods 6: 103-133.

Burachik M (2012) Regulation of GM crops in Argentina. GM Crops \& Foods 3: 48-51.

Carpenter JE (2010) Peer-reviewed surveys indicate positive impact of commercialized GM crops. Nature Biotechnology 28: 219-221.

Carvalho TC, Krzyzanowski FC, Ohlson OC and Panobianco M (2013) Tetrazolium test adjustment for wheat seeds. Journal of Seed Science 35: 361-367.

CropLife International (2010) Compliance management of confined field trials for biotech-derived plants. CropLife International, Brussels, $86 p$.

Devos Y, Dillen K and Demont M (2014) How can flexibility be integrated into coexistence regulations? A review. Journal of the Science of Food and Agriculture 94: 381-387.

Dong S, Liu Y, Yu C, Zhang Z, Chen M and Wang C (2016) Investigating pollen and gene flow of wymv-resistant transgenic wheat n12-1 using a dwarf male-sterile line as the pollen receptor. PLoS ONE 11: 1-14.

Dominguez $\mathrm{CP}$, Batlla $\mathrm{D}$, Rodríguez $\mathrm{MV}$, Windauer $\mathrm{LB}$, Gerbaldo $\mathrm{M}$ and Benech-Arnold RL (2016) Pericarp-imposed dormancy in sunflower: physiological basis, impact on crop emergence, and removal at an industrial scale. Crop Science 56: 716-726.

Edgerton MD, Fridgen J, Anderson Jr. JR, Ahlgrim J, Criswell M,Dhungana P, Gocken T, Li Z, Mariappan S, Pilcher CD, Rosielle A and Stark SB (2012) Transgenic insect resistance traits increase corn yield and yield stability. Nature Biotechnology 30: 493-496.

Garcia-Alonso M, Hendley P, Bigler F, Mayeregger E, Parker R, Rubinstein C, Satorre E, Solari F and McLean MA (2014) Transportability of confined field trial data for environmental risk assessment of genetically engineered plants: a conceptual framework. Transgenic Research 23: $1025-1041$.

Gavassi MA, Fernandes GC, Monteiro CC, Peres LEP and Carvalho RF (2014) Seed germination in tomato: a focus on interaction between phytochromes and gibberellins or abscisic acid. American Journal of Plant Sciences 5: 2163-2169.

Graeber K, Nakabayashi K, Miatton E, Leubner-Metzger G and Soppe
WJ (2012) Molecular mechanisms of seed dormancy. Plant, Cell \& Environment 35: 1769-1786.

Gutiérrez A, Cantamutto M and Poverene M (2012) Introgression of cultivated Sunflower in exotic Helianthus petiolaris populations. Journal of Basic and Applied Genetics 23: 25-36.

Hoffman F, Otto M and Wosniok W (2014) Maize pollen deposition in relation to distance from the nearest pollen source under common cultivation - results of 10 years of monitoring. Environmental Sciences Europe 26: 2-14.

James C (2015) Global status of commercialized biotech/GM crops: 2015. ISAAA, Ithaca. (ISAAA Brief No. 51).

Kavanagh VB, Hills MJ, Eudes F, Topinka K, Yang R and Hall LM (2012) Pollen-mediated gene flow in triticale. Crop Science 52: 2293-2303.

Mallory-Smith C, Hall LM and Burgos NR (2015) Experimental methods to study gene flow. Weed Science 63: 12-22.

Nakai S, Hoshikawa K, Shimono A and Ohsawa R (2015) Transportability of confined field trial data from cultivation to import countries for environmental risk assessment of genetically modified crops. Transgenic Research 24: 929-944

Rentzsch S, Podzimska D, Voegele A, Imbeck M, Müller K, Linkies A and Leubner-Metzger G (2012) Dose and tissue specific interaction of monoterpenes with the gibberellin mediated release of potato tuber bud dormancy, sprout growth and induction of a-amylases and b-amylases. Planta 235: 137-151.

Rieben S, Kalinina O, Schmid B and Zeller SL (2011) Gene flow in genetically modified wheat. PLoS ONE 6: 1-7.

Ryffel GU (2014) Transgene flow: Facts, speculations and possible counter measures. GM Crops \& Foods 5: 249-258.

Sanchez MA, Cid P, Navarrete H, Aguirre C, Chacon G, Salazar E and Prieto $H$ (2016) Outcrossing potential between 11 important genetically modified crops and the Chilean vascular flora. Plant Biotechnology Journal 14: 625-637.

Scaramussa Deprá M, Girondi Delaqua G, Freitas L and Gaglianone MC (2014) Pollination deficit in open-field tomato crops (Solanum lycopersicum L., Solanaceae) in Rio de Janeiro state, Southeast Brazil. Journal of Pollination Ecology 12: 1-8.

Schaart JG, Van de Wiel CC, Lotz LA and Smulders MJ (2016) Opportunities for products of new plant breeding techniques. Trends in Plant Science 21: 438-449.

Stachow U, Bethwell C, Wurbs A and Graef F (2013) Consequences of isolation distances on the allocation of GM maize fields in agricultural landscapes of Germany. Environmental Sciences Europe 25: 24-29.

Tavakoli K, Razavi A and Sohani A (2014) Effects of different temperatures and hormone treatments on breaking dormancy in potato tubers. Journal of Agricultural Science 59: 255-264.

Tsuda M, Okuzaki A, Kaneko Y and Tabei Y (2012) Relationship between hybridization frequency of Brassica juncea $\times B$. napus and distance 
from pollen source (B. napus) to recipient (B. juncea) under field conditions in Japan. Breeding Science 62: 274-81.

Weber EA, Grubera S, Stockmannb F and Claupeina W (2013) Can low-dormancy oilseed rape (Brassica napus) genotypes be used to minimize volunteer problems? Field Crops Research 147: 32-39.
Yan S, Zhu J, Zhu W, Li Z, Shelton AM, Luo J, Cui J, Zhang Q and Liu X (2015) Pollen-mediated gene flow from transgenic cotton under greenhouse conditions is dependent on different pollinators. Scientific Reports 5: $1-9$. 